Biol. Stud. 2018: 12(3-4); 17-26 • DOI: https://doi.org/10.30970/sbi.1203.575

www.http://publications.Inu.edu.ua/journals/index.php/biology

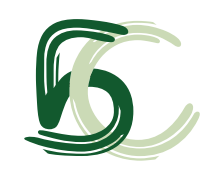

UDC: 597.851:591.151(477.83)

\title{
GENETIC DIVERSITY IN POPULATION SYSTEMS OF GREEN FROGS (PELOPHYLAX ESCULENTUS COMPLEX) IN WATER BODIES OF WESTERN UKRAINE
}

\author{
V. O. Stakh ${ }^{\star 1}$, Iu. M. Strus ${ }^{2,3}$, I. S. Khamar \\ 1 Ivan Franko National University of Lviv, 4, Hrushevskyi St., Lviv 79005, Ukraine \\ ${ }^{2}$ State Museum of Natural History, NAS of Ukraine, 18, Teatralna St., Lviv 79008, Ukraine \\ 3"Roztochia" Nature Reserve, 7, Sichovyh Strilciv St., Ivano-Frankove, Lviv region 81071, Ukraine
}

*e-mail: vasulunastax@gmail.com

Stakh V. O., Strus Iu. M., Khamar I. S. Genetic diversity in population systems of green frogs (Pelophylax esculentus complex) in waterbodies of Western Ukraine. Studia Biologica, 2018: 12(3-4); 17-26 • DOI: https://doi.org/10.30970/sbi.1203.575

The results of the analysis of the genetic structure in population systems of green frogs on the territory of Lviv and Volyn regions are presented. The material was collected in 2011-2012 in water bodies representing three nature regions of Ukraine Forecarpathians, Roztochia, and Western Polissia. Three taxonomic groups of green frogs were in a focus of the study: Marsh frog - Pelophylax ridibundus (Pallas, 1771), Pool frog - Pelophylax lessonae (Camerano, 1882) and their hybrid - Edible frog Pelophylax esculentus (Linnaeus, 1758). DNA was extracted from 91 individuals and analyzed using of 10 pairs of primers: Rrid059, Rrid082, Rrid171, Res5, Res14, Res16, Res22, RICA1b5, RICA18, RICA19. A majority of those are highly polymorphic and diagnostic for species identification. During the analysis, we used programs based on principles of Bayesian statistics and Monte-Carlo Markov Chain algorithms: Structure, BAPS, and NewHybrids. Linkage groups were searched using the GenePop software, and hidden null-alleles were detected using Micro-Checker program. For the first time, in the studied area the genetic structure of populations and population systems were described. After the analysis of genetic diversity of frogs sampled from the Pelophylax ridibundus population and from hemiclonal population systems of mixed R-E-L type, we found that the smallest genetic diversity is observed in the population of Marsh frog from the Nyzhankovychi area (Forecarpathians). More diverse are hemiclonal population systems of green frogs sampled in water bodies of "Cholgynskyi" ornithological reserve (Ukrainian Roztochia) and Shatsk National Nature Park (Western Polissia). Also, for the first time, the hybrid composition of studied localities is described. Hybrids of the first

(C) 2018 V.O. Stakh et al.; Published by the Ivan Franko National University of Lviv on behalf of Біологічні Студії / Studia Biologica. This is an Open Access article distributed under the terms of the Creative Commons Attribution License (http://www.budapestopenaccessinitiative.org/ and Creative Commons Attribution 4.0 License), which permits unrestricted reuse, distribution, and reproduction in any medium, provided the original work is properly cited.

ISSN 1996-4536 (print) • ISSN 2311-0783 (on-line) • Біологічні Студії / Studia Biologica • 2018 • Том 12/№3-4 • С. 17-26 
generation (F1) and backcrosses were detected in water bodies of Shatsk National Nature Park and ornithological reserve "Cholgynskyi".

Keywords: green frogs, microsatellite loci, Structure, BAPS, NewHybrids, backcrosses, water bodies of Western Ukraine

\section{INTRODUCTION}

The group of green frogs (Pelophylax) is known because of a specific way of reproduction of hybrid individuals. In 1964, Polish scientists L. Berger [3] described an exceptional scheme of hybridization between two species of green frogs - Marsh frog Pelophylax ridibundus (Pallas, 1771) and Pool frog - Pelophylax lessonae (Camerano, 1882) with an Edible frog (Pelophylax esculentus (Linnaeus, 1758)) as a result. These three groups of frogs can exist side by side, freely cross-breed and produce hybrids and hemiclonal population systems (HPS) [47]. Somatic cells in hybrids contain halves of genomes of two parental species obtained during fertilization (karyotype is composed of 26 chromosomes; half of each belongs to March frog and another half to Pool frog [38]). Germ cells of hybrids contain only a genome of one of the parental species (R $-P$. ridibundus or $L-P$. lessonae), and another half is eliminated. After the elimination of one half of a genome, the other half undergoes endoreduplication and is called "clonal" (because of the absence of recombination). In fact, it is a copy of the parental genome and usually marked by a capital letter in the parenthesis - (R) and (L), accordingly. Cross-breeding of hybrids with parental species also produces hybrids [32]. Such a way of reproduction is called hemiclonal (Fig. 1).
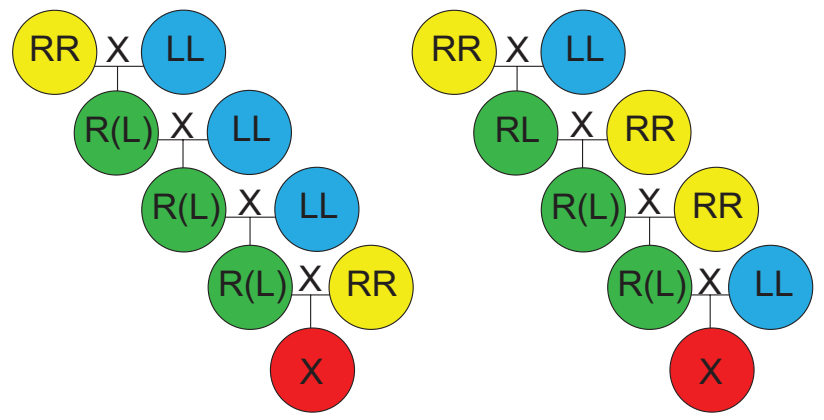

Fig. 1. A scheme of formation and reproduction of hybrid Edible frogs Pelophylax esculentus

Рис. 1. Схеми утворення і відтворення гібридних особин жаби їстівної Pelophylax esculentus

Since 1990-s, a research of genetic structure in green frogs became popular. Analysis of the genetic structure of green frog populations is a powerful tool which allows studying processes unavailable for classical zoological methods. Taking into account a peculiarity of green frogs of West Palearctic, with normal and widespread hemiclonal reproduction [8], usage of classical methods do not show a whole picture of population structure. Therefore, usage of more precise genetic methods is preferable. For instance, barcoding by cytochrome $b$ [14] or electrophoresis of allozyme loci [13] allows precise taxon identification. Also, the method of microsatellite DNA analysis is widespread and available $[13,14,21,24,28,43,49]$. It is frequently used to analyze population structure of green frogs.

ISSN 1996-4536 (print) • ISSN 2311-0783 (on-line) • Біологічні Студії / Studia Biologica • 2018 • Том 12/№3-4 • С. 17-26 
Correct usage of genetic methods is a powerful tool to study population borders [35], introgressions [7], hybridization, variants of backcrosses that can occur in populations or population systems. But genetic methods are also prone to errors [39]. For example, the occurrence of null-alleles can influence the estimation of heterozygosis and ploidy of an individual $[15,55]$. Linkage groups, if not accounted, also lead to an incorrect assessment of population structure [28]. To deal with described possible errors in analysis, special computer programs were developed [8, 32].

Literature review indicates an existence of numerous computer programs that are capable to identify heredity patterns, migrations and genetic isolation of subgroups and use methods of Bayesian statistics: BAPS [11], Bayes [35], BayesAss+ [55], Geneclust Tess [17], Geneland [20], InStruct [18], NewHybrids [1], Partition [11], Structurama [27], Structure [15], GenClon [3]. Majority of them use Markov Chain Monte Carlo approach (MCMC) that is now a standard approach in the Bayesian analysis [17, 39].

The aim of this work was to analyze the genetic structure of population systems of green frogs from different nature regions of Western Ukraine with the usage of modern methods of statistical analysis based on the Bayesian approach. Besides, we wanted to prove a occurrence of hybridization in the studied area and to clarify the origin of hybrids.

\section{MATERIAL AND METHODS}

Greens frogs sampled from three different localities of Lviv and Volyn regions were in the focus of the study. 31 individuals of Marsh frog were sampled in ponds near Nyzhankovychi town (Starosambirskyi district, Lviv region, Forecarpathians, 49 40'17.7' $\mathrm{N}$ and $\left.22^{\circ} 48^{\prime} 15.3^{\prime \prime} \mathrm{E}\right) .42$ individuals of green frogs were sampled from reservoirs in the ornithological reserve "Cholgynskyi" (Yavorivskyi district, Lviv region, Roztochia nature zone, $49^{\circ} 55^{\prime} 03.5^{\prime \prime} \mathrm{N}$ and $23^{\circ} 26^{\prime} 27.6^{\prime \prime} \mathrm{E}$; 18 Pool frogs, 18 Marsh frogs, and 6 hybrids). Also, 21 green frogs in Shatsk National Nature Park (SNNP, 51 $34^{\prime} 06.2^{\prime \prime} \mathrm{N}$ and $23^{\circ} 54^{\prime} 05.1^{\prime \prime} \mathrm{E} ; 5$ Marsh frogs, 1 Pool frog, and 15 hybrids). In total, 94 individuals were collected during 2011-2012, but DNA was successfully extracted from 91 samples. In the paper, enumeration of individuals is given taking into account those three individuals with no DNA extracted (N 3, 32 and 56), because the same enumeration of individuals is used in the set of previous publications [50, 51, 52].

DNA was extracted from samples of muscle tissue stored in $70 \%$ alcohol and also from buccal swabs according to the method of N. Pindasie et al. [37]. For the extraction of DNA, we used universal laboratory sets "Diatom ${ }^{\mathrm{TM}}$ DNA Prep" produced by the "Laboratoriya Isogen". After the analysis of literature and preliminary testing, a set of 10 pairs of primers was selected for the amplification of microsatellite loci of green frogs. Most of loci are highly polymorphic (exactly such are needed for the analysis of clonal individuals [2]) and diagnostic for species identification - Rrid059A, Rrid082A, Rrid171A [25]; Res5, Res14, Res16, Res22 [57]; RICA1b5, RICA18, RICA19 [18]. For the PCR, we used already prepared mixes of reagents specially developed for the PCR-amplification - GenePak® PCR Core produced by "Laboratoriya Isogen". Electrophoretic separation of obtained DNA samples was performed in $6 \%$ polyacrylamide gel with the usage of Tris-BorateEDTA buffer (TBE Buffer). To estimate the length of fragments, a DNA plasmid pBR322 of E. coli prepared by Hpall restriction endonuclease was added to each of the gel plates.

To find possible linkage groups of microsatellite loci GenePop 4.7.0 software was used [44-46]. To find hidden null-alleles Micro-Checker [32] was applied. Allele frequencies and parameters of genetic variability in populations (average number of alleles per

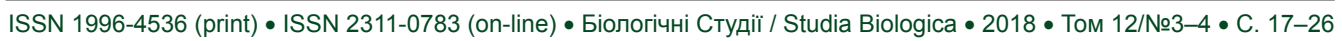


locus, $\left.N_{\mathrm{A}}\right)$, values of observed $\left(H_{\mathrm{O}}\right)$ and expected $\left(H_{\mathrm{E}}\right)$ heterozygosity, fixation index $\left.(\mathrm{F})\right)$ were calculated using GenAIEx 6.503 macros for Microsoft Excel [33], and were tested by us before [50].

The analysis of population structure with the implementation of the Bayesian approach was performed in Structure 2.3.4 [15, 39], BAPS 6.0 [11], and NewHybrids 1.1 [1] programs. For the clusterization in Structure [39] the $K$ value was set in the range between 2 and 7 . Also, 10 runs with the length of burning period equal to 10000 and 100000 iterations (MCMC) were set [13-15, 21, 39]. Optimal number of groups $(K)$ was calculated in Structure Harvester [15]. Multiple results of clusterization from Structure were united in Clumpp [26] to obtain a consensus result. While running BAPS 6.0 [10], according to the recommendations of developers, $K$ value was set equal to $3,5,10$, and 15 [11]. The number of iterations to estimate admixture coefficient was 100; the number of referent populations -200 . As developers recommend selecting a number of iterations for admixture coefficient estimation in the range between 5 and 20, was used 10 [11].

By using the NewHybrids 1.1 program [1], we performed an estimation of the hybridity of individuals in a population based on loci RICA $1 b 5$ and Rrid059A. Those loci were selected because each of them has unique alleles that are fixed in $P$. lessonae (frequency 1,00$)$. Calculations were done using the following settings: the length of burning period equal to 20000 and 200000 iterations (MCMC).

\section{RESULTS AND DISCUSSION}

Alleles of three loci (Rrid059A, RICA1b5, R/CA18) are described in literature [13, $23,41]$ as species-specific, and this tendency is consistent with our data [50]. All obtained genotypes are provided on the web resource [53].

Checking for null-alleles by Micro-Checker program indicated their possible occurrence in locus $R I C A 1 b 5$ in $P$. ridibundus from the "Cholgynskyi" reserve, Res22 in $P$. esculentus from the "Cholgynskyi" reserve, Rrid171A in P. lessonae from the "Cholgynskyi" reserve, Rrid059A in P. ridibundus and Rrid082A in P. esculentus from SNNP. Also, after the analysis of loci in GenePop, we did not find any linkage groups that influenced the estimation of the number of classes [28].

Structure and BAPS programs are not sensitive to the presence of null-alleles [8], but loci with high amount of missing data were excluded from the further analysis [39, 55]: Res5, Res14 and RICA18 (the last locus was not amplified in Marsh frog samples).

The results from Structure and BAPS differ (please check the link [53]) despite the fact that both programs use similar principals and Hardy-Weinberg equilibrium as a basis. Identification in NewHybrids is done on the basis of genotypic frequencies. The program identifies pure species after analysing the unique alleles [1]. In our study, such alleles were found in Rrid059A and RICA1b5 loci.

On the Fig. 2, difference in the taxon composition in samples is noticeable. In water bodies of Nyzhankovychi only Marsh frogs were detected, but in the samples from "Cholgynskyi" reserve and SNNP, all three taxons were found, forming hemiclonal population systems [30, 47] of mixed R-E-L - type.

In the sample from reservoirs in the "Cholgynskyi" reserve, two hybrids ( $\mathrm{N} \mathrm{45,75)}$ of the first generation were found. Also, three backcrosses (Fig. 2) were detected, two of which are the result of hybridization with Marsh frog $(\mathrm{N} \mathrm{61,64)}$ and one with Pool frog (N 69). Despite the occurrence of hybrids, a majority of frogs in the sample are represented by pure parental species. Probably, hybridization of green frogs on this territory

ISSN 1996-4536 (print) • ISSN 2311-0783 (on-line) • Біологічні Студії / Studia Biologica • 2018 • Том 12/№3-4 • C. 17-26 
is a recent phenomenon, or hybridization with individuals of parental species does not always produce viable offsprings. Such a result is consistent with information awailable in the literature $[5,38]$.

Opposite situation in the distribution of taxons and hybrids was found in a sample from SNNP (Fig. 2). The most prominent is prevailing of hybrids of the first generation (N 47-49, 54-58, 86-89, 91, 94) and backcrosses with Marsh frog (N 90, 93) over parental species (N 50-53 - Marsh frog and N 92 - Pool frog). Further perspective of these hemiclonal population systems depends on few factors: genome, which is transferred in hemiclonal way, $((R),(L)$ and simultaneous presence of both variants $-(R)$ and $(L))$; a survival rate of pure species individuals, whose genome is transferred in hemiclonal way (phenomena of hybridolise); a survival rate of hybrids; a possible admixing from the outside [30, 38].

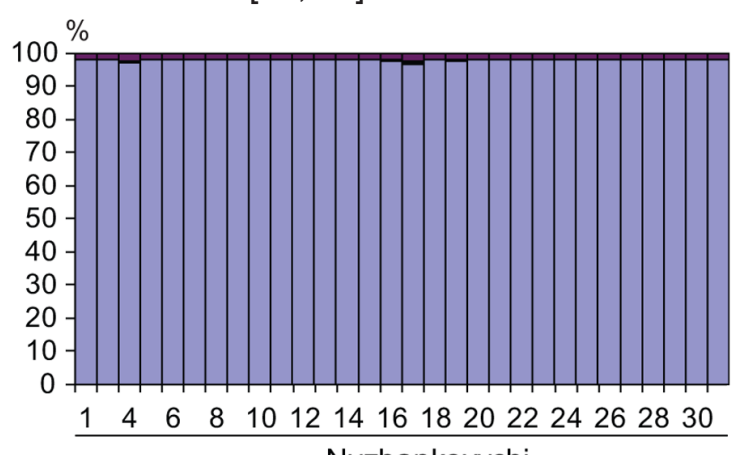

Nyzhankovychi

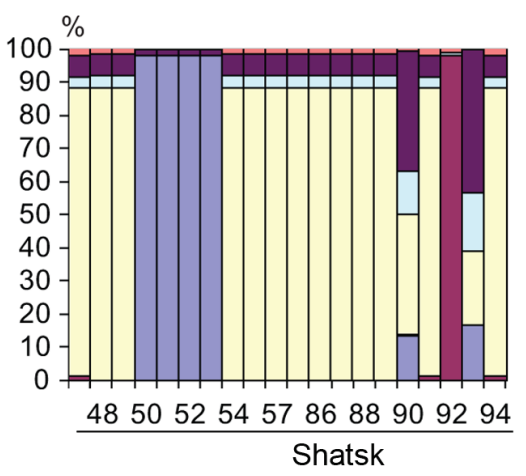

$\square$ P.r.

$\square$ P.I.

$\square \mathrm{F} 1$

$\square \mathrm{F} 2$

$\square \times$ B P.r.

aB_xP.I.

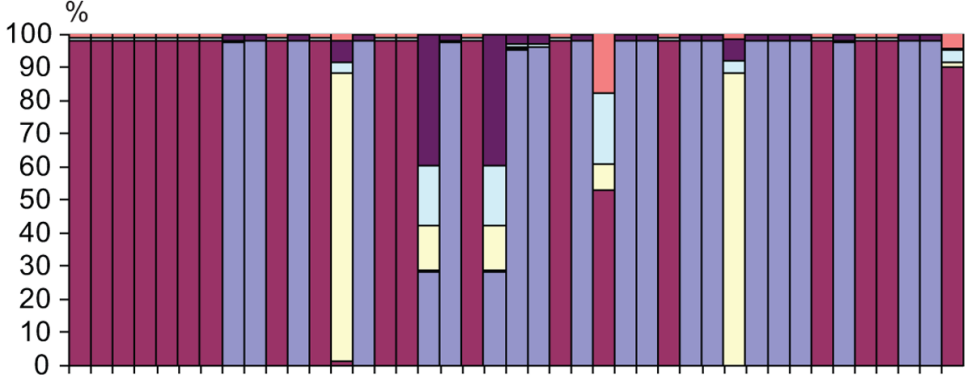

333537394143455961636567697173757779818385

Cholgyni

Fig. 2. Indicator of genetic diversity of green frogs in the Western Ukraine according to the results of analysis in NewHybrids. Each of the vertical bars represents a single frog and numeration below corresponds to that in the text. Numbers 3, 32, and 56 are absent on the diagram because DNA was impossible to extract from those samples. Also, presented numbers are not subsequent because samples were collected not during one field visit (Nyzhankovychi - N 1-31; "Cholgyni" - N 33-46, 59-85; Shatsk N 47-57, 86-94); P. r. - Pelophylax ridibundus, P. I. - P. lessonae, F1 - hybrids of the first generation; F2 - hybrids of the second generation; B_x P.r. - backcrosses with P. ridibundus; B_x P.I. - backcrosses with $P$. lessonae

Рис. 2. Генетичне різноманіття зелених жаб заходу України за результатами аналізу в NewHybrids. Кожен вертикальний стовпчик відповідає одній особині, а номер під стовпчиком - нумерації особин у тексті. На графіках немає особин № 3, 32 та 56, оскільки з відповідних зразків не вдалося виділити ДНК. Також номери особин у виділених вибірках непослідовні, оскільки матеріал відібрано не за один виїзд (Нижанковичі - № 1-31; Чолгині - № 33-46, 59-85; Шацьк - № 47-57, 86-94); P. r. - Pelophylax ridibundus, P. I. - P. lessonae, F1 - гібриди першого покоління; F2 - гібриди другого покоління; В_x P.r. - беккроси із P. ridibundus; B_x P.I. - беккроси із P. lessonae

ISSN 1996-4536 (print) • ISSN 2311-0783 (on-line) • Біологічні Студії / Studia Biologica • 2018 • Том 12/№3-4 • C. 17-26 
In general, the parental species are more diverse and stable in Hardy-Weinberg equilibrium, what is understandable taking into account the taxonomic status of both species - classical species with preservation of all know genetic Mendel laws of heredity. Not such straightforward are laws of heredity in the hybrid Edible frogs. Taking into account clonal transfer of genome (even simultaneous transfer of genomes of both parental species [47, 5]), absence of recombination [29], possible introgression [31, 22], possibility of cross-breeding between hybrids and occurrence of backcrosses, HardyWeinberg equilibrium in such case cannot be used as a criteria of diversity, because all these factors violate it. Because of combining of two parental genomes in one individual, allele diversity in hybrids should be higher. Clonal transfer of a genome across generations will increase total heterozygosity in a population system of hybrids.

\section{CONCLUSIONS}

1. In the studied water bodies on the territory of Western Ukraine, a population of Marsh frogs (in Nyzhankovychi area) and R-E-L-type of hemiclonal population system in the "Cholgynskyi" reserve (43\% Marsh frogs, $43 \%$ Pool frogs, and $14 \%$ hybrids) and SNNP (24\%, $5 \%$, and $71 \%$, respectively) were detected.

2. Pure populations of the parental species are more stable and less diverse in the Hardy-Weinberg equilibrium than hemiclonal population systems with hybrids. A genetic diversity of detected population systems differs. Individuals from the samples taken in the "Cholgynskyi" reserve show higher diversity than such from the SNNP.

3. Hybrid individuals of green frogs sampled in the "Cholgynskyi" reserve are more diverse by origin. Among the six hybrids, two are a result of cross-breeding of parental species (F1) and four are backcrosses produced after cross-breeding with Marsh frog $(n=2)$ and Pool frog $(n=2)$. A majority of individuals in samples from SNNP are hybrids of the first generation $(n=13)$; other two are backcrosses with Marsh frog.

4. A occurrence of primary hybridization (between parental species) resulting in hybrids of the first generation was confirmed on the studied territory ( $47 \%$ of F1 hybrids were mature individuals).

1. Anderson E., Thompson E. A model-based method for identifying species hybrids using multilocus genetic data. Genetics, 2002; 160(3): 1217-1229.

[PMID: 11901135]

2. Arnaud-Haond S., Alberto F., Teixeira S. et al. Assessing genetic diversity in clonal organisms: low diversity or low resolution? Combining power and cost efficiency in selecting markers. Journal of Heredity, 2005; 96(4): 434-440.

[DOI: https://doi.org/10.1093/jhered/esi043]

3. Arnaud-Haond S., Belkhir K. GENCLON: a computer program to analyse genotypic data, test for clonality and describe spatial clonal organization. Molecular Ecology Notes, 2007; 7: 15-17. [DOI: https://doi.org/10.1111/j.1471-8286.2006.01522.x]

4. Berger $L$. Is Rana esculenta lessonae Camerano a distinct species? Annales Zoologici, 1964; 22(13): 245-261.

5. Berger L., Berger A. Persistence of all-hybrid water frog populations (Rana kl. esculenta) in northern German. Genet. Pol, 1994; 35(1-2): 73-80.

6. Biriuk O., Shabanov D., Korshunov O. et al. Gamete production patterns and mating systems in water frogs (hybridogenetic Pelophylax esculentus complex) in North-Western Ukraine. Journal of Zoological Systematics and Evolutionary Research, 2015; 54(3): 215-225. [DOI: https://doi.org/10.1111/jzs.12132]

ISSN 1996-4536 (print) • ISSN 2311-0783 (on-line) • Біологічні Студії / Studia Biologica • 2018 • Том 12/№3-4 • C. 17-26 
7. Bohling J.H., Adams J.R., Waits L.P. Evaluating the ability of Bayesian clustering methods to detect hybridization and introgression using an empirical red wolf data set. Molecular Ecology, 2013; 22: 74-86.

[DOI: https://doi.org/10.1111/mec.12109]

8. Carlsson J. Effects of microsatellite null alleles on assignment testing. Journal of Heredity, 2008; 99 (6): 616-623.

[DOI: https://doi.org/10.1093/jhered/esn048]

9. Charney N. D. Relating hybrid advantage and genome replacement in unisexual salamanders. Evolution, 2011; 66-5: 1387-1397.

[DOI: https://doi.org/10.1111/j.1558-5646.2011.01523.x]

10. Corander J., Marttinen P., Sirén J. et al. Enhanced Bayesian modelling in BAPS software for learning genetic structures of populations. BMC Bioinformatics, 2008; 9: 539: 1-14. [DOI: https://doi.org/10.1186/1471-2105-9-539]

11. Corander J., Cheng L., Marttinen P. et al. BAPS: Bayesian Analysis of Population Structure. Manual v. 6.0. Department of Mathematics and statistics University of Helsinki, 2013. 28 p.

12. Dawson K., Belkhir K. A Bayesian approach to the identification of panmictic populations and the assignment of individuals. Genetical Research, 2001; 78(1): 59-78. [DOI: https://doi.org/10.1017/S001667230100502X]

13. Doležálková M., Pruvost N. B. M., Plötner J. et al. All-male hybrids of a tetrapod Pelophylax esculentus share its origin and genetics of maintenance. Biology of Sex Differences, 2018; 9(13): 1-11.

[DOI: https://doi.org/10.1186/s13293-018-0172-z]

14. Dufresnes C., Denoël M., di Santo L. et al. Multiple uprising invasions of Pelophylax water frogs, potentially inducing a new hybridogenetic complex. Scientific reports, 2017; 7: 6506: 1-9. [DOI: https://doi.org/10.1038/s41598-017-06655-5]

15. Earl D.A., VonHoldt B.M. STRUCTURE HARVESTER: a website and program for visualizing STRUCTURE output and implementing the Evanno method. Conserv. Genet. Resour, 2012; 4: 359-361.

[DOI: https://doi.org/10.1007/s12686-011-9548-7]

16. Falush D., Stephens M., Pritchard J.K. Inference of population structure using multilocus genotype data: dominant markers and null alleles. Molecular Ecology Notes, 2007; 7: 574-578.

[DOI: https://doi.org/10.1111/j.1471-8286.2007.01758.x]

17. François O., Ancelet S., Guillot G. Bayesian clustering using hidden Markov random fields in spatial population genetics. Genetics, 2006; 174(2): 805-816

[DOI: https://doi.org/10.1534/genetics.106.059923]

18. Gao H., Williamson S., Bustamante C. A Markov chain Monte Carlo approach for joint inference of population structure and inbreeding rates from multilocus genotype data. Genetics, 2007; 176(3): 1635-1651.

[DOI: https://doi.org/10.1534/genetics.107.072371]

19. Garner T.W.J., Gautschi B., Rothlisberger S. et al. Set of CA repeat microsatellite markers derived from the pool frog, Rana lessonae. Molecular Ecology, 2000; 9: 2155 - 2234. [DOI: https://doi.org/10.1046/j.1365-294X.2000.105311.x]

20. Guillot G., Santos F., Estoup A. Analysing georeferenced population genetics data with Geneland: a new algorithm to deal with null alleles and a friendly graphical user interface. Bioinformatics, 2008; 24(11): 1406-1407. [DOI: https://doi.org/10.1093/bioinformatics/btn136]

21. Herczeg D., Vörös J., Christiansen D.G. et al. Taxonomic composition and ploidy level among European water frogs (Anura: Ranidae: Pelophylax) in eastern Hungary. J Zool Syst Evol Res, 2017; 55(2): 129-137. [DOI: https://doi.org/10.1111/jzs.12158]

22. Hoffmann A., Plötner J., Pruvost N. et al. Genetic diversity and distribution patterns of diploid and polyploid water frogs (Pelophylax esculentus) across Europe. Molecular Ecology, 2015; 24(17): 4371-4391.

[DOI: https://doi.org/10.1111/mec.13325]

ISSN 1996-4536 (print) • ISSN 2311-0783 (on-line) • Біологічні Студії / Studia Biologica • 2018 • Том 12/№3-4 • C. 17-26 
23. Holm S. A simple sequentially rejective multiple test procedure. Scandinavian Journal of Statistics, 1979; 6(2): 65-70.

24. Hotz H., Uzzel T. Biochemically Detected Sympatry of Two Water Frog Species: Two Different Cases in the Adriatic Balkans (Amphibia, Ranidae). Proceedings of the Academy of Natural Sciences of Philadelphia. 1982; 134: 50-79.

25. Hotz H., Uzzel T., Guex G.-D. et al. Microsatellites: a tool for evolutionary genetic studies of western Palearctic water frogs. Mitt. Mus. Nat. kd. Berl., Zool. Reihe, 2001; 77(1): 43-50. [DOI: https://doi.org/10.1002/mmnz.20010770108]

26. Jakobsson M., Rosenberg N.A. CLUMPP: a cluster matching and permutation program for dealing with label switching and multimodality analysis of population structure. Bioinformatics, 2007; 23: 1801-1806.

[DOI: https://doi.org/10.1093/bioinformatics/btm233]

27. Huelsenbeck J., Andolfatto P. Inference of population structure under a Dirichlet process model. Genetics, 2007; 175(4): 1787-1802.

[DOI: https://doi.org/10.1534/genetics.106.061317]

28. Kaeuffer R., Reale D., Coltman DW. et al. Detecting population structure using STRUCTURE software: effect of background linkage disequilibrium. Heredity, 2007; 99: 374-380.

[DOI: https://doi.org/10.1038/sj.hdy.6801010]

29. Kanginakudru S., Metta M., Jakati R.D. et al. Genetic evidence from Indian red jungle fowl corroborates multiple domestication of modern day chicken. BMC Evolutionary Biology, 2008; 8:174: 1-14.

[DOI: https://doi.org/10.1186/1471-2148-8-174]

30. Kravchenko M.A., Shabanov D.A. Possible Ways of Transformation of Population Systems of Pelophylax esculentus complex (Ranidae, Anura, Amphibia). Proceeding of the Ukranian Herpetological Society, 2008; 1: 15-20. (In Russian).

31. Nekrasova O.D. Interspecific Variability and Colouring Polymorphism of Green Frogs Rana esculenta Complex (Amphibia, Ranidae) in Hybrid Populations. Vestnik zoologii, 2002; 36(4): 47-54. (In Russian).

32. Ogielska M. Reproduction of amphibians. Enflield, NH: Science Publishers, 2009. 422 p.

33. Oosterhout van C., Hutchinson W.F., Wills D.P.M. et al. MICRO-CHECKER: software for identifying and correcting genotyping errors in microsatellite data. Molecular Ecology Notes, 2004; 4: 535-538.

[DOI: https://doi.org/10.1111/j.1471-8286.2004.00684.x]

34. Peakall R., Smouse P. GenAlEx 6.5: Genetic analysis in Excel. Population genetic software for teaching and research-an update. Bioinformatics, 2012; 28: 2537-2539.

[DOI: https://doi.org/10.1093/bioinformatics/bts460].

35. Pella J., Masuda M. The Gibbs and split-merge sampler for population mixture analysis from genetic data with incomplete baselines. Canadian Journal of Fisheries and Aquatic Sciences, 2006; 63(3): $576-596$.

[DOI: https://doi.org/10.1139/f05-224]

36. Perez-Enriquez R., Medina-Espinoza J.A., Max-Aguilar A. et al. Genetic tracing of farmed shrimp (Decapoda: Penaeidae) in wild populations from a main aquaculture region in Mexico. Rev. Biol. Trop, 2018; 66(1): 381-393.

[DOI: https://doi.org/10.15517/RBT.V66I1.27112]

37. Pidancier N., Miquel C., Miaud C. Buccal swabs as a non-destructive tissue sampling method for DNA analysis in amphibians. Herpetological Journal, 2003; 13(4): 175-178.

38. Plötner J. Die westpaläarktichen Wasserfrösche. Bielefeld: Laurenti-Verlag, 2005. $161 \mathrm{p}$.

39. Pompanon F., Bonin A., Bellemain E. et al. Genotyping errors: causes, consequences and solutions. Nature reviews: Genetics, 2005; 6: 847-859.

[DOI: https://doi.org/10.1038/nrg1707]

40. Pritchard J.K., Stephens M., Donnelly P. Inference of population structure using multilocus genotype data. Genetics, 2000; 155 (2): 945-959.

[PubMed: 10835412]

ISSN 1996-4536 (print) • ISSN 2311-0783 (on-line) • Біологічні Студії / Studia Biologica • 2018 • Том 12/№3-4 • C. 17-26 
41. Pruvost N.B.M., Hoffmann A., Reyer H.-U. Gamete production patterns, ploidy, and population genetics reveal evolutionary significant units in hybrid water frogs (Pelophylax esculentus). Ecology and Evolution, 2013; 3(9): 2933-2946.

[DOI: https://doi.org/10.1002/ece3.687]

42. Pruvost N.B.M., Mikulicek P., Choleva L., Reyer H.-U. Contrasting reproductive strategies of triploid hybrid males in vertebrate mating systems. Journal of Evolutionary Biology, 2015; 28: 189-204.

[DOI: https://doi.org/10.1111/jeb.12556]

43. Quilodran C.S., Montoya-Burgos J.I., Currat M. Modelling interspecific hybridization with genome exclusion to identify conservation actions: the case of native and invasive Pelophylax waterfrogs. Evolutionary Applications, 2015; 8(2): 199-210.

[DOI: https://doi.org/10.1111/eva.12245]

44. Raymond M., François R. GENEPOP Version 1.2: Population Genetics Software for Exact Tests and Ecumenicism. J Heredity, 1995; 86(3): 248-249.

45. Rousset F., Raphaël L. Likelihood and approximate likelihood analyses of genetic structure in a linear habitat: performance and robustness to model mis-specification. Mol. Biol. Evol, 2007; 24(12): 2730-2745.

[DOI: https://doi.org/10.1093/molbev/msm206]

46. Rousset F., Raphaël L. Likelihood-Based Inferences Under Isolation by Distance: Two-Dimensional Habitats and Confidence Intervals. Mol. Biol. Evol, 2012; 29(3): 957-973. [DOI: https://doi.org/10.1093/molbev/msr262]

47. Shabanov D.A., Korshunov O.V., Kravchenko M.O. Which of the water frogs inhabit Kharkiv oblast? Perspectives on terminology and nomenclature. Proceedings of G.S. Skovoroda National Pedagogic University of Kharkiv. Biology and Valeology, 2009; 11: 116125. (In Ukrainian).

48. Shabanov D.A., Litvinchuk S.N. Green frogs: life without rules or a special way of evolution? Priroda, 2010; 3: 29-36. (In Russian).

49. Smouse P.E., Banks S.C., Peakall R. Converting quadratic entropy to diversity: Both animals and alleles are diverse, but some are more diverse than others. PLOS ONE, 2017; 12(10): 1-19. [DOI: https://doi.org/10.1371/journal.pone.0185499]

50. Stakh V., Belokon M., Khamar I. at al. Morphological and genetic polymorphism of green frogs (Pelophylax) in water bodies of Western Ukraine. Visnyk of the Lviv University. Series Biology, 2014; 64: 241-249. (In Ukrainian).

51. Stakh V., Reshetylo O., Khamar I. Inter-population morphometric variability of Pelophylax ridibundus (Anura, Amphibia) in the water bodies of Lviv province. Visnyk of the Lviv University. Series Blology, 2016; 72: 180-186.

52. Stakh V.O., Khamar I.S., Reshetylo O.S., Zabytivskyi Yu.M. Phenes of water frogs (Pelophylax) as the indicators of water bodies' contamination in Pre-Carpathians, Roztochia, Lesser and Western Polissia. Studia Biologica, 2017; 11(1): 161-168.

[DOI: https://doi.org/10.30970/sbi.1101.523]

53. Stakh V. Population structure of green frogs in Western Ukraine according to the results of analysis in Structure, BAPS and NewHybrids. Mendeley Data, v1, 2018. [DOI: https://doi.org/10.17632/bc99z4z4hy.1]

54. Stakh $V$. The genotypes of green frogs from water bodies of Western Ukraine. Mendeley Data, v1, 2018.

[DOI: https://doi.org/10.17632/w2w2cjcvjp.1]

55. Wagner A.P., Creel S., Kalinowski S.T. Estimating relatedness and relationships using microsatellite loci with null alleles. Heredity, 2006; 97: 336-345.

[DOI: https://doi.org/10.1038/sj.hdy.6800865].

56. Wilson G., Rannala B. Bayesian inference of recent migration rates using multilocus genotypes. Genetics, 2003; 163(3): 1177-1191.

[PubMed: 12663554]

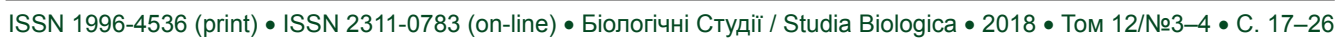


57. Zeisset I., Rowe G., Beebee T.J.C. Polymerase chain reaction primers for microsatellite loci in the north European water frogs Rana ridibunda and $R$. lessonae. Molecular Ecology, 2000; 9(8): 1173-1174.

[DOI: https://doi.org/10.1046/j.1365-294x.2000.00954-2.x]

58. Zimovin A.I. Bayes factor vs. p-value: evaluation of statistical hypotheses likelihood in psychology. Technologies of intellect development, 2016; 14: 1-18. (In Russian).

\title{
ГЕНЕТИЧНЕ РІЗНОМАНІТТЯ ПОПУЛЯЦІЙНИХ СИСТЕМ ЗЕЛЕНИХ ЖАБ (PELOPHYLAX ESCULENTUS COMPLEX) ВОДОЙМ ЗАХОДУ УКРАЇНИ
}

\author{
B. O. Cmax ${ }^{* 1}$, Ю. M. Сmpyc ${ }^{2,3}$, I. C. Хамар ${ }^{1}$ \\ ${ }^{1}$ Львівський національний університет імені Івана Франка \\ вул. Грушевського, 4, Львів 79005, Україна \\ ${ }^{2}$ Державний природознавчий музей НАН України, вул. Театральна, 18, Львів 79008, Україна \\ ${ }^{3}$ Природний заповідник "Розточчя" \\ вул. Січових Стрільців, 7, Івано-Франкове, Львівська обл. 81071, Україна \\ *e-mail: vasulunastax@gmail.com
}

У роботі представлено результати аналізу генетичної структури популяційних систем зелених жаб Львівської та Волинської областей. Матеріал відібрано у 2011 2012 роках із водойм трьох природних регіонів західної України - Передкарпаття, Українського Розточчя (Львівська обл.) та Західного Полісся (Волинська обл.). Об'єктом роботи були особини трьох таксономічних груп зелених жаб (рід Pelophylax), які поширені на території України, а саме: жаба озерна - Pelophylax ridibundus (Pallas, 1771), жаба ставкова - Pelophylax lessonae (Camerano, 1882) та їхній гібрид - жаба їстівна - Pelophylax esculentus (Linnaeus, 1758). ДНК виділено із 91 особини земноводних і проаналізовано з використанням 10 пар праймерів: Rrid059A, Rrid082A, Rrid171A, Res5, Res14, Res16, Res22, RICA1b5, RICA18, RICA19. Більшість із використаних маркерів $є$ високополіморфними та діагностичними для визначення виду. Під час аналізу використано програми, які працюють на принципах баєсівської статистики і алгоритмі Монте-Карло на основі ланцюгів Маркова (МСМС), a саме: Structure, BAPS та NewHybrids. За допомогою програми GenePop здійснено пошук груп зчеплення, а для пошуку прихованих null-алелей використовували програму Micro-Checker. Уперше для зелених жаб досліджуваної території встановлено генетичну структуру популяцій і популяційних систем. Проаналізувавши генетичне різноманіття земноводних, відібраних із популяції Pelophylax ridibundus і геміклональних популяційних систем (ГПС) змішаного типу, а саме R-E-L-Tипу, найменше генетичне різноманіття виявлено в популяції жаби озерної (смт Нижанковичі, регіон Передкарпаття). Більш різноманітними $є$ аналізовані геміклональні популяційні системи зелених жаб, відібраних із водойм орнітологічного заказника "Чолгинський" (Українське Розточчя) та Шацького національного природного парку (Західне Полісся). Також уперше встановлено гібридний склад популяційних систем досліджуваних локалітетів. Виявлено гібридів першого покоління (F1) та беккросів у водоймах Шацького національного природного парку й орнітологічного заказника “Чолгинський”.

Ключові слова: зелені жаби, мікросателітні локуси, Structure, BAPS, NewHybrids, беккроси, водойми Західної України

Одержано: 13.11 .2018

ISSN 1996-4536 (print) •ISSN 2311-0783 (on-line) • Біологічні Студії / Studia Biologica • 2018 • Том 12/№3-4 • C. 17-26 